\title{
TÁRSAS KAPCSOLATOK
}

\section{CSALÁDI, ROKONI, BARÁTI KAPCSOLATOK NYÍREGYHÁZA LAKÓI KÖRÉBEN 2008-2010}

\author{
HuSzTi Éva
}

\begin{abstract}
Social contacts. Family, relatives, friendship among the population of Nyíregyháza 2008-2010. The study presents social contacts of habitants of Nyíregyháza, mainly focusing on strong ties like connections with members of family, relatives, friends and neighbours. The paper gives a picture about the dynamic of social contacts: how the numbers of friends shaped during the examined period; from whom the inhabitants of Nyíregyháza can expect social supports and how the support system changed around people. In addition, we could examine the shape of community life, club life, membership of organisations, associations, etc. among adult population. Using the method of name generator, we studied people's strong ties along three situations: illness, free time activities, intimacy. This study summarizes how the improvements and negative changes took place in addition with social connections during 2008-2010 in Nyíregyháza.
\end{abstract}

Keywords: social network, social connections, string ties, solidarity, social support system, friendship, neighbourhood

DOI: $10.19055 / \mathrm{ams} .2012 .3 / 3 / 10$

\section{ELŐLJÁRÓBAN}

A Nyíregyháza életminőségét vizsgáló háztartás panel vizsgálat úgymond általánosnak számító kérdéskörei közé, mint a háztartásokra vonatkozó kérdések, a megkérdezettek gazdasági aktivitása, egészségi helyzete, stb. mellé bekerült a társas kapcsolatok vizs gálata is. Így lehetőség nyílt arra, hogy több kérdés, több dimenzió mentén vizsgáljuk meg az ország kilenc legnagyobb városa egyikének társas kapcsolatmintázatát. A társas kapcsolatok jelentőségét egyrészt az adja, hogy ezeken a kapcsolatokon társadalmi eröforrások áramlanak. Logikusnak tủnik azt feltételezni, hogy akik kiterjedt kapcsolatrendszerrel bírnak több és színesebb erőforráshoz jutnak. Ez azonban nem minden 
esetben van így. Az egocentrikus kapcsolati hálókban lévő kötéseknek Granovetter alapján két típusát különböztetjük meg: erős illetve gyenge kötéseket. Az erős kötések közé soroljuk általában a közeli családtagokat (szülők, gyerekek, testvérek, házastárs), illetve a barátokat. Azok, akik sok erős kötéssel rendelkeznek, sűrü kapcsolati hálót mondhatnak magukénak, ahol szinte mindenki ismer mindenkit. Ezek a hálók multiplexek, azaz egy-egy kapcsolat többféle szerepet is betölt, többféle feladatot is ellát, ezen kívül homofíl kapcsolatok jellemzőek, azaz a hálóbeli tagok sok tekintetben hasonlítanak egymásra (pl.nem, kor, iskolai végzettség). Az erős kapcsolatoknak kicsi az úgynevezett híd szerepe, tehát elsősorban a mikrotársadalmi integrációt segíti elö. Az erős kapcsolatokban gazdag egocentrikus kapcsolati hálók általában az alacsony társadalmi státusszal köthetők össze. A gyenge kötésekhez általánosságban a szomszédokat, ismerősöket, régebbi osztálytársakat, tanárokat, stb. soroljuk. A gyenge kötések szerepe a híd funkciójukban áll, ami azt jelenti, hogy ezek a kötések képesek a makrotársadalmi integrációt elősegíteni azáltal, hogy különböző társadalmi csoportokat tudnak összekötni. A gyenge kapcsolatokban gazdag hálók általában ritkásak, nem ismer mindenki mindekit, alacsony a multiplexitása is, inkább az uniplex kapcsolatok jellemzőek. Ilyen kapcsolati hálóval leginkább a magasabb társadalmi státuszúak rendelkeznek.

A modernizáció, az individualizáció, az informatikai vívmányok terjedése során többször felmerült annak a problematikája, hogy a modern társadalmakból eltüntek a hagyományos, rokonsági és szomszédsági szolidaritás elemei (társadalmi dezintegráció elmélete, ,elveszett közösségek” elmélet). Többeknek viszont azt sikerült bizonyítani, hogy a fejlett társadalmakban nincs eltűnőben a hagyományos szolidaritás, csak átalakul: az önzetlenséget elváró altruista szolidaritás tartalma csökken, a kölcsönösségi, viszonossági szolidaritás tartalma, reciprocitás-értéke pedig erösödik. Több kutatás is alátámasztotta, hogy azok az egyének, akik bármilyen társadalmi támaszt kapnak, elégedettebbek az életkörülményeikkel, boldogabbak és kiegyensúlyozottabbak, pozitívan értékelik életminőségüket, tehát a társas támogatottság mértéke meghatározó része a szubjektív életminőségnek.

Jelen tanulmány a 2008-ban és 2010-ben felvett Nyíregyháza Város Életminősége Háztartáspanelből származó adatbázisra támaszkodva próbál képet alkotni arról, hogy mennyire integrálódott be a helyi közösségbe egy átlag nyíregyházi polgár, milyen kapcsolati potenciálokkal rendelkezik. Ennek során lesz szó a barátok számának alakulásáról, a társas támogatás müködéséről, valamint a közösségi lét néhány dimenziójáról.

\section{EGY KIS ISMÉTLÉS}

2008-ban felvett adataink alapján többek között arra a következtetésre jutottunk, hogy Nyíregyházán is, mint az ország egyéb településein, vannak úgynevezett kapcsolat- vagy forráserős társadalmi csoportok, illetve vannak olyanok, akikre inkább a kapcsolathiány jellemző. A Nyíregyháza életminőségét vizsgáló panelkutatás első hullámából származott adatok azt mutatták, hogy városunkban a forráserős csoporthoz a fiatalok, iskolázottak, és a férfiak tartoznak, ha a barátokkal való kapcsolatot vesszük figyelembe. Ez kiegészül a jómódúak csoportjával, akik a közösségi lét szempontjából számítanak a kapcsolaterősek 
közé, azaz ők azok, akik inkább részt vesznek a helyi társadalom mindennapjaiban. A kapcsolathiányban szenvedők az idősek, az alacsonyabb iskolai végzettséggel rendelkezők és a nők, ha a barátkozási potenciálokat nézzük, valamint a szegényebb rétegekhez tartozók azok, akik nagyobb eséllyel maradnak ki a közösségi életből.

\section{A BARÁTOK SZÁMÁNAK ALAKULÁSA 2008-2010}

2010-ben a megkérdezett nyirregyháziak átlagosan 5,98 baráttal számolhattak. Ez kicsivel magasabb, mint a 2008-ban mért 5,52-es átlag. A nők átlagosan 6,28 baráttal rendelkeznek, míg a férfiak 5,62 barátot tudhatnak maguk mellett. 2008-ban a nök 5,15, míg a férfiak 5,96 barátot jelöltek meg. Láthatjuk tehát, hogy Nyíregyházán az elmúlt két évben jelentösen növekedett a nök átlagos barátszáma, mig a férfiak körében ez némiképp csökkent.

A Háztartások Életút Vizsgálata (HÉV) jelentés 2007-es adatai szerint a megkérdezetteknek átlagosan 7,99 barátjuk van $(\mathrm{N}=2628)$. A férfiak 9,51 $(\mathrm{N}=1145)$, a nők 6,82 $(\mathrm{N}=1483)$ baráttal bírnak. Látható tehát, hogy Nyíregyházán a nök számoltak be több barátról, míg az országos adatok szerint a férfiaknak van átlagosan több barátjuk. (1. ábra)

\section{"Hány barátja van Önnek?"}

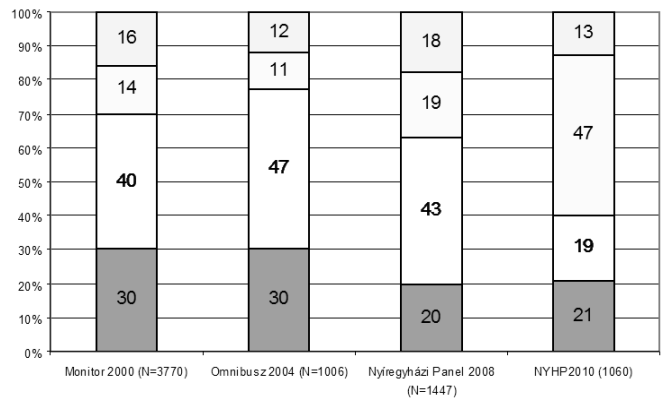

$\square$ 10-nél több barát 5 -9 barát

1-4 barát

$\square$ egy sincs

1. ábra - Hány barátja van Önnek? Forrás: Albert F.-Dávid B., (2007.) felhasználásával saját szerkesztés.

A nyíregyházi mintában 2008-hoz képest a legjelentösebb változás az 1-4 baráttal rendelkezök arányának jelentős csökkenése (43\%-ról 19\%-ra), és ezzel párhuzamosan az 5-9 baráttal bírók arányának növekedése volt (19\%-ról 47\%-ra). (2. ábra)

A nyiregyházi fiatalok 2010-ben kicsivel kevesebb barátot jelöltek meg átlagosan, míg mind a középkorúak, mind az idősebbek valamivel több barátról számoltak be, mint két évvel ezelött. A fiatalok minimális barátvesztése abból adódik, hogy itt a 1834 éves korosztályt soroltuk ebbe a kategóriába. A korcsoport végén azonban növeked- 
het a tartós kapcsolatba lépők, családalapítók aránya, mely életjelenségek a barátok időleges hanyagolásával jár együtt. (3. ábra)

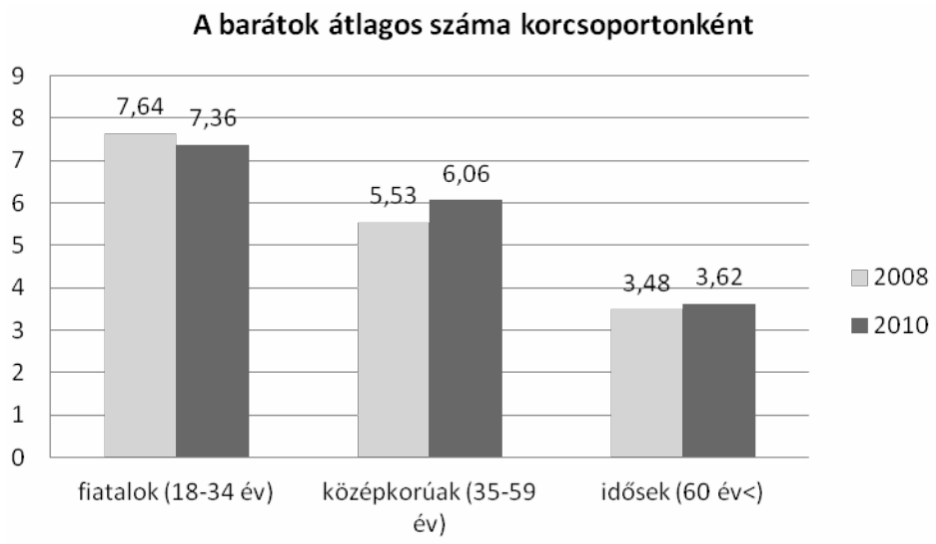

2. ábra - A barátok átlagos száma korcsoportonként.

A barátok átlagos száma iskolai végzettség szerint

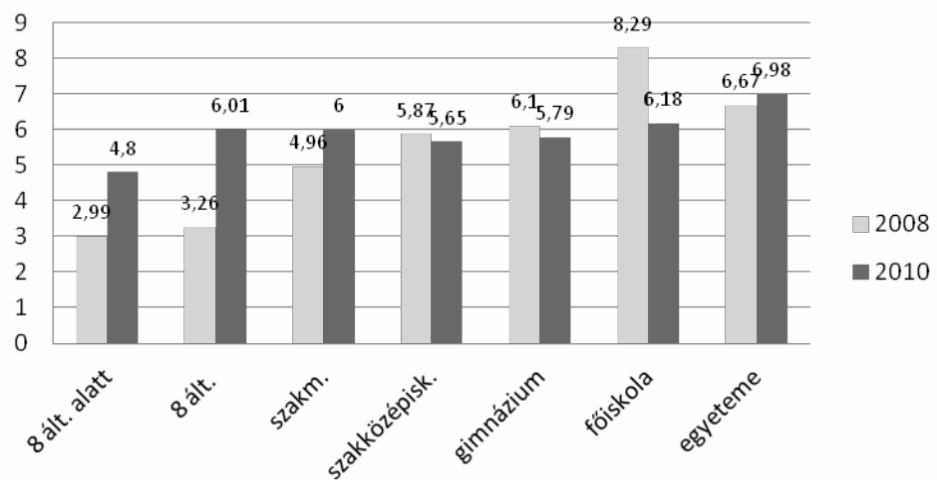

3. ábra - A barátok átlagos száma iskolai végzettség szerint.

2008-hoz képest a városban növekedett a legalacsonyabb iskolai végzettséggel rendelkezők barátainak átlagos száma. A szakközépiskolai végzettségtől felfelé haladva pedig rendre csökken a 2010-ben megjelölt barátok átlagos száma. Az egyetemi végzettséggel rendelkezők körében is csak minimális, pozitív irányú elmozdulásról beszélhetünk. Ez értelmezhető egyrészről pozitív jelenségként is, hiszen a vizsgált két évben növekedni látszik az alacsony iskolai végzettségủek társadalmi integrációja, ami a barátok átlagos számának növekedését illeti. (4. ábra) 


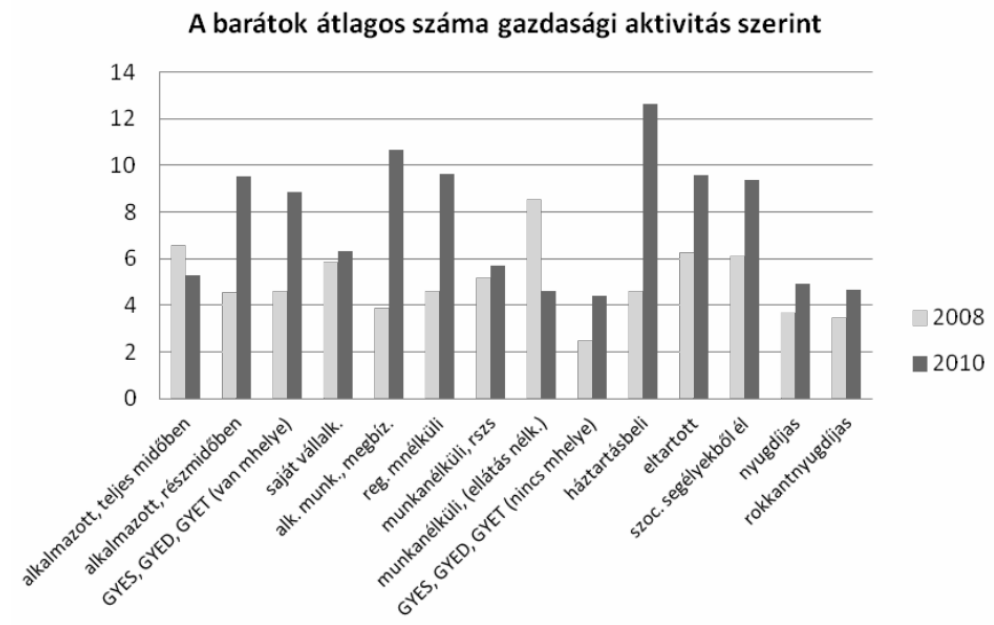

4. ábra - A barátok átlagos száma gazdasági aktivitás szerint.

A megkérdezettek gazdasági aktivitását vizsgálva megállapíthatjuk, hogy az elmúlt két évben Nyiregyházán két csoportnak csökkent jelentösen a barátok átlagos száma: a teljes munkaidőben foglalkoztatott alkalmazottak és a mindenféle ellátás nélkül élö munkanélküliek körében. Minden más foglalkoztatási csoportban növekedést lehet detektálni, közülük is kiemelendő a részmunkaidőben alkalmazottak, a munkahellyel rendelkező gyesen, gyeden lévő kismamák, az alkalmi munkát végzők, a regisztrált munkanélküliek nyugdíjasok. Azonban az alacsony esetszám miatt ez utóbbi változásokat nem lehet populációs szinten is értelmezni.

A barátok átlagos számának csökkenését a teljes munkaidőben foglalkoztatottak körében magyarázhatjuk azzal, hogy akik foglalkoztatva vannak, olyan sokat dolgoznak, hogy nem jut idejük a barátságok ápolására. Az ellátás nélkül élő munkanélküliek esetében pedig a társadalmi izolálódásról lehet szó, hiszen valószínűleg ők már azért nem kapnak semmiféle ellátást, mert hosszú ideje munkanélküliek, amivel együtt jár, hogy megszakadtak kapcsolataik.

Angelusz Róbert és Tardos Róbert vizsgálataiból tudjuk, hogy megnövekedett a szerepe a munkaerö-piaci jelenlétnek. Az aktívak és az inaktívak a kapcsolathálózati erőforrás tekintetében két különálló világra szakadtak, mely szakadék az életkor elörehaladtával egyre csak növekszik. (Angelusz R.-Tardos R., 2006) (1. táblázat)

Az országos adatokhoz képest Nyíregyházán továbbra is kevesebb baráttal rendelkeznek átlagosan a 44 év alatti aktív férfiak és nők is. Ez jellemző a 44 év feletti férfi akra is.A 44 év feletti nök esetében a nyiregyháziak rendelkeznek átlagosan több baráttal és ez az elmúlt két évben tovább fokozódott, lévén nőtt az ebbe csoportba tartozók barátainak átlagos száma (4,94-ről 5,99-re). A 44 év alatti aktív nők esetében Nyíregy- 
házát vizsgálva elmondható, hogy 2010-ben átlagosan kevesebb baráttal rendelkeznek, mint 2008-ban. A 44 év alatti és feletti férfiak esetében már 2008-ban is kevesebb barátot regisztráltunk, mint az országos átlag. Ez a különbség tovább nött, hiszen a nyíregyházi férfiak a barátvesztők körébe tartoznak az elmúlt két évet tekintve. A munkanélküliek csoportját vizsgálva azt látjuk, hogy az országos átlaghoz képest némiképp elmaradott szinten stagnál a barátok átlagos száma Nyíregyházán. (A munkanélküliek kategóriája ebben az esetben magába foglalja mind a regisztrált, mind az ellátással rendelkező, mind az ellátás nélküli, valamint a gyesen, gyeden lévő munkanélkülieket.) A háztartásbelieket, eltartottakat figyelembe véve megállapítható az erőteljes növekedés, de az esetszám meglehetősen alacsony, nem vonhatunk le messzemenő következtetéseket. A városban élő nyugdíjasok barátainak átlagos száma az elmúlt két évben növekedett, és ha kevéssel is, de meghaladta az országos átlagot.

\begin{tabular}{|l|r|r|r|r|r|r|}
\hline & \multicolumn{2}{|l|}{ Országos $2007^{*}$} & \multicolumn{2}{l|}{ Nyíregyháza 2008 } & \multicolumn{2}{l|}{ Nyíregyháza 2010} \\
\hline & Átlag & \multicolumn{1}{l|l}{ N } & \multicolumn{1}{l|}{ Átlag } & \multicolumn{1}{l|}{ N } & \multicolumn{1}{l|}{ Átlag } & N \\
\hline 44 év alatti aktív férfi & 11,4 & 356 & 7,61 & 258 & 6,08 & 149 \\
\hline 44 év alatti aktív nő & 8,1 & 285 & 7,15 & 237 & 5,51 & 269 \\
\hline 44 év feletti aktív férfi & 7,1 & 231 & 4,55 & 161 & 5,3 & 135 \\
\hline 44 év feletti aktív nő & 4,8 & 241 & 4,94 & 155 & 5,99 & 174 \\
\hline Munkanélküli & 7,6 & 202 & 6,19 & 50 & 6,2 & 63 \\
\hline Htb és egyéb inaktív & 6,5 & 193 & 4,82 & 96 & 10,29 & 24 \\
\hline Nyugdíjas & 4,4 & 833 & 3,66 & 435 & 4,94 & 219 \\
\hline
\end{tabular}

1. táblázat - A barátok átlagos száma a megkérdezettek gazdasági aktivitása és nemek szerint. *HÉV 2008 jelentés.

\section{CSALÁDI ÁLLAPOT ÉS A BARÁTOK ÁTLAGOS SZÁMA}

Több kutatás is foglalkozott már azzal, hogy a családi állapot fontos befolyásoló tényező lehet bizonyos cselekvéseket, tevékenységet tekintve. Adataink szerint szignifikáns öszszefüggés van a barátok száma és a megkérdezett családi állapota között. Úgy tünik, a barátság létesítése és ápolása különbözik az eltérő családi állapotú egyéneknél. (5. ábra)

Családi állapot szerint Nyiregyházán a barátvesztők körébe a nötlenek és hajadonok tartoznak, bár még így is a legtöbb baráttal rendelkeznek átlagosan. A többi kategóriában a barátok átlagos számának növekedését regisztráltuk az elmúlt két évben. A nőtlenek és hajadonok körében történő visszaesés magyarázható azzal, hogy bár családi állapotukat tekintve ebbe a kategóriába sorolták magukat az általában 18-29 év közötti megkérdezettek, de esetleg meglévő tartós, de nem élettársi, párkapcsolatuk stabilizálódott, így a baráti társaságok jelentősége csökkent számukra. Utasi Ágnes szerint 
(Utasi, 1990) hazánkban az önálló életkezdés nagyon nagy terheket ró a fiatalok vállára. Olyannyira, hogy kapcsolataikat, instrumentális célok szerint alakítják, ahol kevésbé van jelentősége az érzelmeken alapuló barátságnak. (Dávid B. - Albert F., 2005)

\section{A barátok átlagos száma a megkérdezett családi állapota szerint}
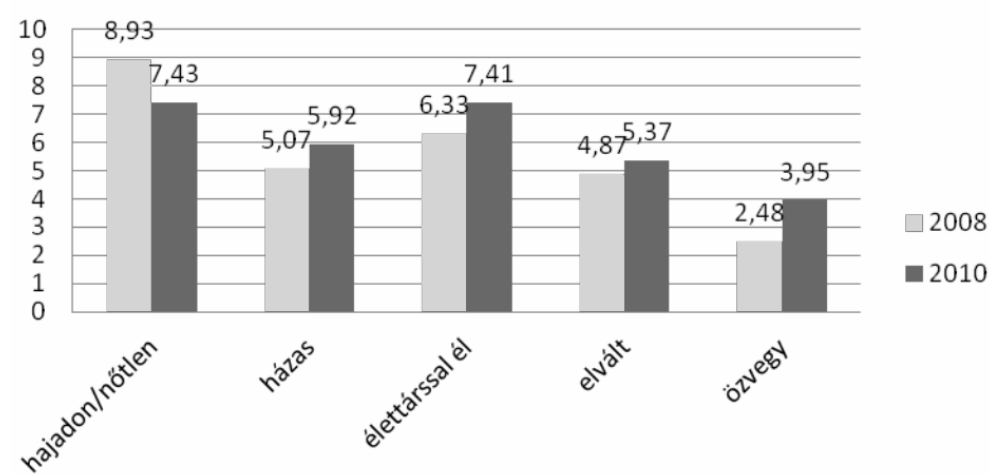

5. ábra - A barátok átlagos száma a megkérdezett családi állapota szerint.

\section{EGÉSZSÉGI ÁLLAPOT ÉRTÉKELÉSE ÉS A BARÁTOK ÁTLAGOS SZÁMA}

\section{A barátok átlagos száma az egészségi állapot szubjektív megítélése szerint}

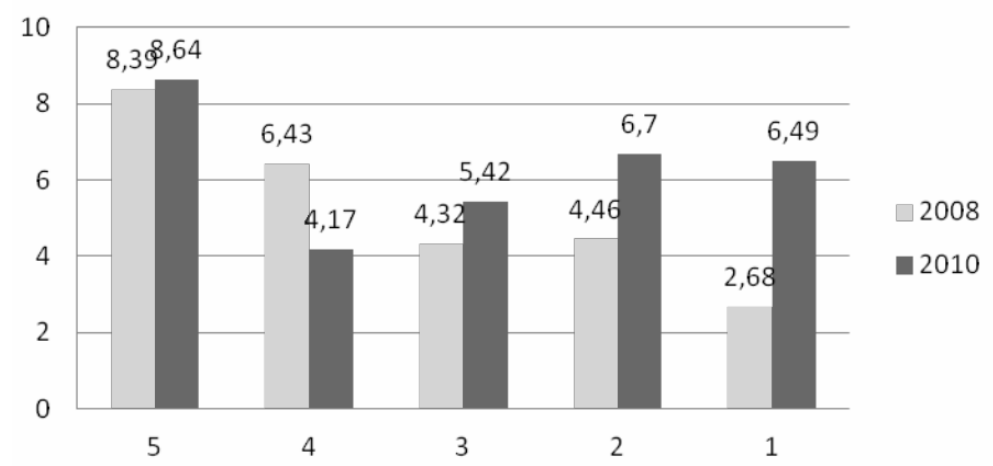

6. ábra - A barátok átlagos száma az egészségi állapot szubjektív megítélése szerint.

Szignifikáns összefüggés van a barátok száma és a megkérdezettek szubjektív egészségi 
állapota között. Az adatok szerint 2008-ról 2010-re csak azoknak csökkent a barátainak átlagos száma, akik jónak (4) minősitették egészségi állapotukat. Minden más kategóriában növekedést tapasztaltunk. Érdemes kiemelni, hogy azok, akik egészségi állapotukat nem minősítették jónak, 2010-ben több baráttal bírtak átlagosan, mint azok, akik szubjektíve jobban érezték magukat. Erre a nem túl általánosnak mondható jelenségre egyébként a kötet egy másik tanulmánya is utal. (A szubjektív egészségi állapot meghatározó tényezői Nyíregyházán) A szerzők ott, a barátok számát tekintve az itt említettektől eltérő kategóriákat használnak, de az eredmények összecsengenek. (6. ábra)

\section{A BARÁTOK SZÁMÁT BEFOLYÁSOLÓ TÉNYEZŐK}

Arra a kérdésre kerestük a választ, hogy mi befolyásolja azt, hogy valakinek hány barátja van. Az elemzéshez lineáris regresszióanalízist végeztünk. Az elemzésben a függő változó tehát a barátok száma, a függetlenek pedig: a kor; nem; iskolai végzettség; gazdasági aktivitás; családi állapot; szubjektív egészségi állapot, társadalmi réteg. A felsorolt független változók mindegyike szignifikáns kapcsolatban van a függő változóval.

A barátok számát legerőteljesebben a megkérdezettek szubjektív egészségi állapota magyarázza. Ezt követi az egyén iskolai végzettsége.

Tehát, azoknak van több barátja, akik szubjektíve jobban értékelik egészségi állapotukat és magas iskolai végzettséggel rendelkeznek. A harmadik magyarázó változó a megkérdezett családi állapota, mely erősen hat a barátok számának alakulására. Mivel az iskolai végzettség és a szubjektív egészségi állapot között összefüggés van, - mint ahogyan az a kötetnek A szubjektív egészségi állapot meghatározó tényezői Nyíregyházán címü fejezetben a szerzők részletesebben is elemzik, - a végső modell szerint azt, hogy valakinek hány barátja van, az befolyásolja leginkább, hogy milyen iskolai végzettséggel rendelkezik az illető. A következő legerősebb magyarázó változó a szubjektív egészségi állapot, a harmadik legerősebb pedig a megkérdezett családi állapota. A végső modellbe nem kerültek be a következő változók: nem; gazdasági aktivitás; réteghelyzet.

\section{A BARÁtVÁlaszTás TEREPEI}

A barátok legnagyobb arányban 2010-ben is a munkatársak közül került ki 2010-ben a barátok közül átlagosan 2,76 rekrutálódott erről a terepröl, míg 2008-ban 2,9. A volt iskolatársak közül 2,3 (2,2 2008-ban), a szomszédok közül pedig 1,9 (1,7 2008-ban). Jól látható tehát, hogy nincs jelentös változás a két évvel ezelötti adatokhoz képest. A barátválasztás terepei az országoshoz hasonló gyakorisággal jelennek meg a nyíregyházi mintában is.

\section{A „HÁROM BARÁT” VIZSGÁLAT}

Azt kértük a válaszadóktól, hogy nevezzék meg három legjobb barátjukat és jellemez- 
zék ezeket a megnevezett barátokat különböző paraméterek alapján. Ilyenek voltak: a barát neme, kora, iskolai végzettsége, lakóhelye, foglalkozása, munkahelye, stb. Ebből a vizsgálatból megtudhatjuk, hogy az adott egyén hogyan választ barátot, mi alapján szelektál. Inkább a hozzá hasonló egyénekkel keresi a barátságot (hasonlósági elv = like me), vagy ellenkezőleg, a tőle eltérö jellemzőkkel bíró emberek közül választ barátot. Itt megfigyelhetjük az ún. presztízs elvet is, ami azt jelenti, hogy az emberek sokszor választanak olyan barátot, akik tőlük felfelé helyezkednek el a társadalmi ranglétrán, azaz „felfelé választanak”. Kutatások azt igazolták, hogy akármelyik elv alapján is választ az egyén barátokat, még mindig valószínübb, hogy a szolidaritás valamelyik típusa megjelenik ezekben a kapcsolatokban, mint azoknál, akik egyáltalán nem rendelkeznek baráttal. (Utasi, 2002)

A nyiregyházi férfiak és nök körében is erös homogén választás jellemzö a korosztályokat tekintve. Az első három felsorolt barátot mind a férfiak, mind pedig a nők leginkább saját korcsoportjukból választják. A megkérdezett kora és az általa megjelölt barát kora között mindkét nem esetében és mindhárom megjelölt barátnál szignifikáns összefüggést találtunk, tehát megállapításainak vonatkoztathatjuk Nyíregyháza város lakosaira.

Iskolai végzettséget tekintve is erös összefüggést, tehát inkább homogén választásokat találunk a nők esetében. A férfiak esetében is mindhárom barát iskola végzettsége szignifikáns kapcsolatot mutat a megkérdezett iskolai végzettségével, ezzel is erősítve a homogén barátválasztás képét.

\section{SEGÍTSÉGNYÚJTÁS KÜLÖNBÖZÖ HELYZETEKBEN 2010 BEVEZETŐ SZÖVEG}

Az egyének egymás iránti szolidaritásukat kifejezhetik anyagi vagy szimbolikus eröforrások áramoltatásával: nyújthatnak egymásnak hasznos információkat; közbenjárhatnak valahol valakinek az érdekében; érzelmi támogatást nyújthatnak azzal, hogy meghallgatják egymást; elmennek együtt valahová; stb. Ennek az a lényege, hogy ezek az eröforrások más típusú tökévé alakulhatnak, igy elösegithetik a társadalom integrációját. Az egyének közötti szolidaritás kedvez a közösségi kohézió, igy a mikrotársadalmi integráció kialakulásának. A mikrotársadalmi integráció célja, hogy az adott közösség ne szakadjon szét, a közösség tagjai ne izolálódjanak. A különböző szolidaritásforrások társadalmi rétegenként, csoportonként eltérö súllyal esnek latba, de a tradicionális, közösségi kapcsolatokból eredő szolidaritás kiemelkedő szerepet kap minden csoport esetében. (Utasi, 2002)

A panelvizsgálatban 2008-ban három, 2010-ben pedig négy kérdés mentén vizsgáltuk azt, hogy a megkérdezettek, szubjektív megítélésük szerint számíthatnak-e rokonaik, családtagjaik, illetve barátaik, ismerőseik támogatására az adott kérdésben. (2. táblázat)

2008-ról 2010-re nőtt azok aránya, akiknek van olyan rokona, vagy családtagja, illetve barátja, ismerőse, aki segítséget tud nyújtani iskoláztatással, továbbtanulással 
kapcsolatban, illetve, aki jó orvost tud ajánlani adott esetben.

A jó állás, munkahely megszerzéséhez a barátok segítségnyújtásának nagyobb szerepe lehet a nyíregyháziak esetében.

\begin{tabular}{|l|l|l|l|l|}
\hline & \multicolumn{2}{|l|}{ Rokona, családtagja van (\%) } & \multicolumn{2}{l|}{ Barátja, ismerőse van (\%) } \\
\hline & 2010 & 2008 & 2010 & 2008 \\
\hline $\begin{array}{l}\text { Segítséget nyújt, vagy nyújtott } \\
\text { Önnek hivatalos ügyintézéshez } \\
\text { (pl. önkormányzati engedélyek, } \\
\text { kölcsönök, hitelek, } \\
\text { szerződéskötések stb.)? }\end{array}$ & 50 & 50 & 40 & 30 \\
\hline $\begin{array}{l}\text { Segítséget nyújtott iskoláztatás- } \\
\text { sal, továbbtanulással kapcsolat- } \\
\text { ban, } \\
\text { Aki például bejuttatta egyetemre } \\
\text { vagy jó szakmát } \\
\text { nyújtó iskolába? }\end{array}$ & 18 & 16 & 19 \\
\hline $\begin{array}{l}\text { Segítséget nyújt vagy nyújtott } \\
\text { egy jó állás, munkahely } \\
\text { megszerzéséhez? }\end{array}$ & 25 & n.a. & 30 & n.a. \\
\hline $\begin{array}{l}\text { Betegség esetén segít vagy segí- } \\
\text { tett jó orvost szerezni? }\end{array}$ & 55 & 47 & 45 & 33 \\
\hline
\end{tabular}

2. táblázat

Összevont változó mentén vizsgálva azt tapasztaltuk, hogy tovább csökkent azok aránya (31,7\%-ról 24,6\%-ra), akik egyik vizsgált területen sem számíthatnak sem rokoni, sem pedig baráti, ismerősi segítségnyújtásra. Ez jó jele lehet a mikrotársadalmi szolidaritás erősödésének.

Ahogyan azt a kötet Támogató rendszerek, szociális problémák és segélyezés címü fejezetében is olvashatjuk, szociális problémák esetén a nyíregyháziak elsősorban a család segítségét veszik igénybe. A mesterséges támogató rendszert pedig megelőzik a barátoktól, ismerősöktől igényelt támogatás.

Megvizsgáltuk azt is, hogy hogyan változott a különböző helyzetekben nyújtott segítség az országos és a korábbi városi adatokhoz képest.

A hivatalos ügyintézésben nyújtott családi, rokoni segitség aránya az elmúlt két évben nem változott Nyíregyházán, igy még mindig az országos átlag alattinak mondható. A barátoktól várt segítségnyújtás viszont tovább erősödött a városban, így azt mondhatjuk, hogy Nyíregyházán a hivatalos ügyintézésben a barátoknak nagyobb szerepe van - és ez a szerep csak tovább fokozódott, - mint a családtagoknak, rokonoknak.

A jó állás, munkahely megszerzéséhez Nyíregyházán mind a családtagok, rokonok, mind a barátok jelentősebb segítséget nyújthatnak, mint az országban általánosan. Ez az arány az elmúlt két évben tovább növekedett. 
A nyíregyháziak betegség esetén is nagyobb segitséget várhatnak mind családtagjaiktól, rokonaiktól, mind pedig barátaiktól, mint országosan. Itt is növekedésről lehet beszélni, ami a városi adatokat illeti.

Mindez erösíti azt a fentebbi megállapítást, hogy úgy tünik, Nyíregyházán növekedett a mikrotársadalmi szolidaritás, az egyének kapcsolati hálója sürübb és kiterjedtebb lett, az ezeken áramló eröforrások pedig egyre több egyént integrálnak az adott közösségbe.

\section{KÖZÖSSÉGI, SZERVEZETI ÉLET, KLUBTAGSÁG}

A klub és szervezetbeli tagságot vizsgálva készítettünk a 2010-es adatokra is egy öszszevont változót, mely azt méri, hogy a megkérdezettek közül hányan tagjai legalább egyfajta klubnak/szervezetnek illetve, hogy hányan vannak olyanok, akik egynél több szervezethez tartoznak. Az adatok szerint a mintába került városlakók közül minden negyedik tagja legalább egy $(19,6 \%)$ valamilyen, általunk felsorolt klubnak vagy szervezetnek, és csupán további $7,1 \%$ az, aki egynél több szervezethez csatlakozott. $A$ megkérdezetteknek továbbra is majdnem háromnegyede (73,3\%)nem tartozik semmilyen klubhoz vagy szervezethez sem. (7. ábra)

"Tagja-e Ön valamilyen klubnak vagy szervezetnek?" (\%)

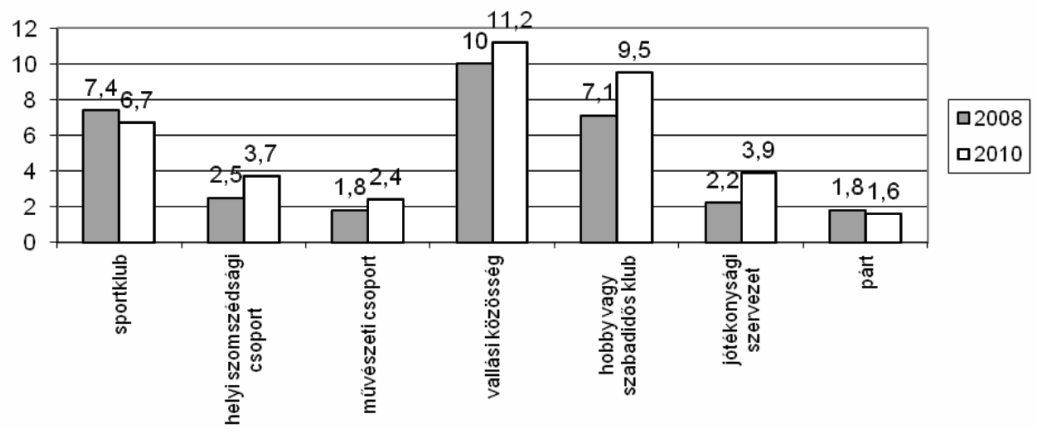

7. ábra - Tagja-e Ön valamilyen klubnak, vagy szervezetnek?

A 2010-es adatok szerint a nyíregyháziak kisebb arányban tartoznak valamilyen sportklubhoz, mint két évvel korábban, illetve a valamilyen párthoz való tartozásuk mutat nagyon alacsony elmozdulást a negatív irányba. Viszont növekedni látszik azok aránya, akik valamilyen hobby vagy szabadidös klubhoz, valamilyen helyi szomszédsági csoporthoz, müvészeti csoporthoz, jótékonysági szervezethez vagy vallási közösséghez tartoznak. Mindez megerösíti a fenti „érzést”, miszerint mintha növekedne a helyi közösség életébe való bekapcsolódás, mintha jobban ér- 
deklődnének az emberek egyrészt a szabadidő hasznos eltöltése iránt, másrészt pedig az őket körülvevő mikroközösség iránt.

Vizsgáljuk meg kicsit közelebbröl, kik azok, akik abba a 25\%-ba tartoznak, akik tagjai valamilyen klubnak, szervezetnek, járnak valamilyen közösségbe.

Ha az életkor mentén vizsgálódunk, azt látjuk, hogy némiképp változott a helyzet 2008-hoz képest, hiszen 2010-ben azok között, akik valamilyen szintü közösségi életet élnek, most a fiatalok vannak nagyobb arányban, az idösekhez képest. A középkorúak megőrizték vezető helyüket e tekintetben. (8. ábra)

\section{Klubtagság társadalmi rétegek szerint}

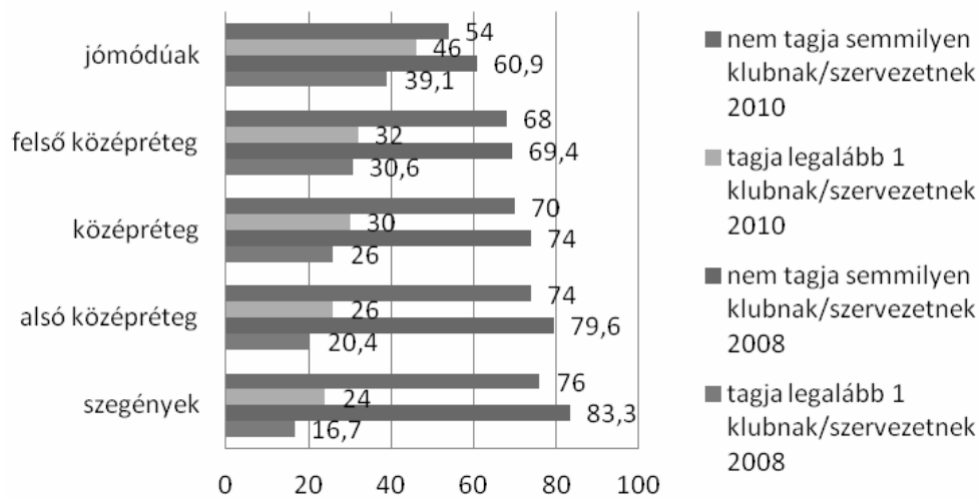

8. ábra - Klubtagság társadalmi rétegek szerint. (2008 - Chi-square $=21,913 ; \mathrm{DF}=4$; $\mathrm{p}<0,001 ; 2010$ - Chi-square $=12,349 ; \mathrm{DF}=4 ; \mathrm{p}<0,05)$

A társadalmi rétegek tekintetében elmondható, hogy minden réteg esetében csökkent azok aránya, akik nem tartoznak semmilyen szervezethez, klubhoz az általunk felsoroltak közül. Viszont arra is fel kell hívni a figyelmet, hogy továbbra is jellemzö az, hogy minél jobb módú a megkérdezett, annál valószinübb, hogy tagja legalább egy, általunk felsorolt közösségnek.

A következő rétegképző változó, amely mentén a klubtagságot vizsgáltuk az isko lai végzettség volt. Az összefüggés itt is szignifikáns volt. (9. ábra)

Amint láthatjuk, kicsit átrendeződött a 2008-ra jellemző egyenes összefüggés az iskolai végzettség és a klubtagság között. 2010-re növekedett az alacsony iskolai végzettségüek és a szakmunkások aránya azok között, akik valamilyen szervezethez, klubhoz tartoznak. A szakközépiskolát végzettek aránya nem változott, míg a gimnáziumi végzettséggel birók aránya némiképp csökkent. Nagyobb arányú csökkenés jellemzö azonban az egyetemet végzettek között. Az adatok szerint a vizsgált két év során míg az alacsony iskolai végzettségüek nagyobb arányban csatlakoztak bármely, általunk felsorolt közösségi, szervezeti lehetőséghez, addig az egyetemet végzettek leggyakrabban a sportklubokból maradtak ki. Valószínü, hogy a szociális ellátórendszerek által nyújtott 
lehetőségeket az alacsony iskolai végzettségüek jobban ki tudják aknázni, míg a kvalifikáltabbak számára is vonzóbb klubok, szervezetek kínálata szükös.

\section{Klubtagság iskolai végzettség szerint}

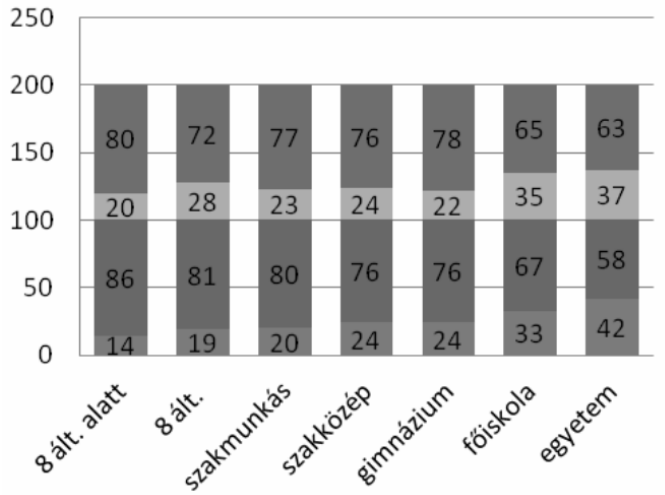

nem tagja semmilyen
klubnak/szervezetnek
2010
tagja legalább 1
klubnak/szervezetnek
2010
nem tagja semmilyen
klubnak/szervezetnek
2008
tagja legalább 1
klubnak/szervezetnek
2008

9. ábra - Klubtagság iskolai végzettség szerint.

\section{A ROKONOKKAL, BARÁTOKKAL, SZOMSZÉDOKKAL VALÓ KAPCSOLATTARTÁS JELLEMZÖI}

\section{A kapcsolattaratások gyakorisága 2008/2010}
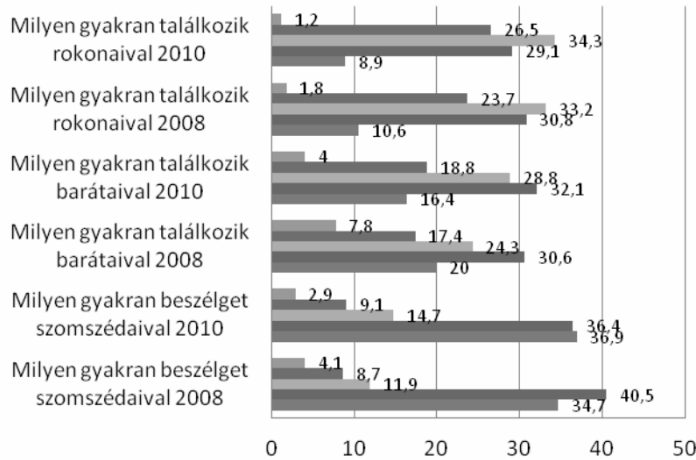

10. ábra - A kapcsolattartások gyakorisága 2008/2010.
- soha

ritkábban mint havonta

—1-2 alk./hó

घ1-2 alk./hét

nindennap

A szomszédokkal való beszélgetés gyakorisága a vizsgált két évben a következőképpen változott: kevéssel növekedett a szomszédaival naponta beszélgetök aránya, de ez- 
zel párhuzamosan csökken a heti rendszerességgel beszélgetök aránya. Növekedett a szomszédaival ritkábban (1-2 alkalom havonta; ritkábban, mint havonta) beszélgetök aránya. Ez a helyi szomszédságok szolidaritásnyújtási potenciálját tekintve nem nevezhetö kedvezö elmozdulásnak.

A barátokkal való találkozást vizsgálva azt láthatjuk, hogy csökkent a mindennapos kapcsolattartás és a havi rendszeres találkozás is. Növekedett a heti rendszeresség, valamint a ritka alkalmakkor való találkozás.

A rokonokkal való találkozás rendszeressége csökkent az elmúlt két évben Nyíregyházán, gyakoribbá vált a havi, vagy éves találkozás.

\section{A SZOMSZÉDOKKAL VALÓ KAPCSOLATTARTÁS JELLEMZÖI 2010-BEN}

A szomszédokkal való mindennapos kapcsolattartás a gazdasági szempontból aktívakra, a saját vállalkozásban dolgozókra, illetve a nyugdíjasokra jellemzö leginkább. Továbbra is jellemzö, hogy a kisgyermekes szülök szomszédaikkal gyakori leginkább mindennapos kapcsolatot tartanak. A munkanélküliek, valamint a rokkant nyugdíjasok heti rendszerességgel ápolják a szomszédi kapcsolatokat. Azok között, akik nem tartják egyáltalán szomszédaikkal a kapcsolatot, a rokkantnyugdíjasok vannak a legtöbben.

Korcsoportokat vizsgálva megállapíthatjuk, hogy a fiatalokra (18-34 év) a heti, illetve a mindennapos kapcsolattartás a legjellemzőbb, ami a szomszédokat illeti. Ugyanez jellemzö a középkorúakra is (35-59 év). És továbbra is elmondható, hogy a 60 év felettiek azok, akik a szomszédokkal leggyakrabban tartják a kapcsolatot. A középkorúak azok, akikre legjellemzőbb a szomszédokkal való ritka vagy egyáltalán nem ápolt kapcsolat.

A szomszédokkal való kapcsolattartás gyakoriságát elemezve érdemes kiemelni, hogy minél fentebb megyünk a különbözö társadalmi rétegekben, a szegényektöl a jómódúak felé egyre csökken a szomszédokkal való mindennapos és a gyakori kapcsolattartás. A szomszédsági kapcsolatok kevésbé önkéntes alapúak. A szomszédokkal fenntartott kapcsolat általában gyenge kötésnek, kapcsolatnak számít, se nem aktív, se nem intim. Viszont fizikai közelsége miatt elég gyakoriak, sủrü kapcsolathálót alkotnak. A szomszédok tudnak egymás problémáiról, és könnyen tudnak segítséget nyújtani. Általában is jellemző, hogy az alacsonyabb iskolai végzettségüeknél és alacsonyabb réteghelyzetủeknél jelentősebb a szomszédi kapcsolatok erőforrás áramoltató funkciója. (Szabó, 2003) Az alacsonyabb társadalmi helyzetben élők gyakrabban töltik mindennapjaikat otthon, nagyobb esély van a szomszédokkal való napi szintü kapcsolattartásra. A jobb módúak pedig vagy a munkával töltött idő mennyisége miatt, vagy pedig egyfajta osztályspecifikus elkülönülés miatt kevesebb kontaktust létesítenek szomszédaikkal.

A panelvizsgálatban használt változók közötti összefüggés azonban nem szignifikáns, tehát csak a vizsgált mintára jellemző az eredmény. 


\section{A BARÁTOKKAL VALÓ KAPCSOLATTARTÁS GYAKORISÁGA 2010-BEN}

Gazdasági aktivitást tekintve az alkalmazottak barátaikkal leginkább hetente, illetve havonta 1-2 alkalommal találkoznak. A gyesen, gyeden lévőkre a barátokkal való ritkább, inkább a havi kapcsolattartás jellemző. Akik saját vállalkozásban tevékenykednek, hetente 1-2 alkalommal találkoznak barátaikkal. A munkanélküliek egyik csoportja hetente, másik csoportja pedig inkább ritkábban, mint havonta tartja barátaival a kapcsolatot. A háztartásbeliekre, eltartottakra a barátokkal való gyakori kapcsolattartás jellemző, míg a nyugdíjasok havonta, vagy még ennél is ritkábban találkoznak barátaikkal. A rokkantnyugdíjasokra a heti, havi 1-2 találkozás jellemző.

A korosztályokat megvizsgálva elmondható, hogy a fiatalok inkább heti vagy havi rendszerességgel tartják a kapcsolatot barátaikkal. A középkorúak körében a legjellemzőbb a barátokkal való mindennapos találkozás. A 60 év felettiek leginkább havonta jönnek össze barátaikkal.

Az adatok szignifikáns összefüggést jeleztek az egyén egészségi állapota és a barátokkal való kapcsolattartás gyakorisága között: akinek rossz az egészségi állapota, az havonta, aki jónak vagy kielégítőnek értékelte saját egészségi állapotát, hetente vagy ennél is gyakrabban találkozik barátaival.

Megvizsgáltuk a társadalmi rétegeket is abból a szempontból, hogy milyen gyak ran találkoznak barátaikkal. Azt találtuk, hogy a barátokkal való mindennapos kapcsolattartás a középrétegekre jellemzö leginkább. Kiemelendö, hogy a szegényekre jellemzőbb a barátokkal való rendszeres és gyakori kapcsolattartás, mint a jómódúak csoportjába tartozókra. A jómódúak a barátokkal leginkább havonta járnak össze. Ugyanez jellemző az alsó középrétegre is. A felső középréteg a barátokkal való heti találkozást preferálja. A két vizsgált változó között szignifikáns kapcsolatot mértünk.

A barátokkal való kapcsolattartást összevetettük országos adatokkal. (11. ábra)

Milyen gyakran találkozik barátaival?

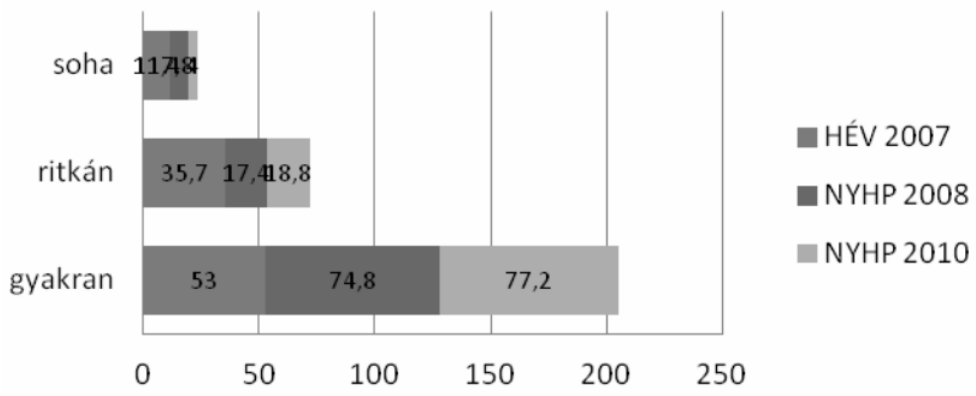

11. ábra - Milyen gyakran találkozik barátaival? 
A fenti ábrán látható, hogy városunkban a barátokkal való gyakori találkozás már 2008-ban is magasabb volt, mint az országban mért, és ez 2010-re további növekedést mutat. A barátokkal való ritkább találkozás alacsonyabb szintủ Nyíregyházán, mint az országban, még akkor is, ha a városban kicsit nőtt ez az arány az utóbbi vizsgálat óta.

\section{A ROKONOKKAL VALÓ KAPCSOLATTARTÁS GYAKORISÁGA 2010-BEN}

Gazdasági aktivitást tekintve az alkalmazottak rokonaikkal leginkább havonta tartják a kapcsolatot, míg a gyesen, gyeden lévők illetve a saját vállalkozásban dolgozókra a heti kapcsolattartás jellemző. A munkanélküliek és a nyugdíjasok ritkábban, mint havonta találkoznak rokonaikkal. A rokkant nyugdíjasokra a havi kapcsolattartás jellemző.

A szubjektív egészségi állapotot vizsgálva a rokonokkal való kapcsolattartás az egészségi állapotukat rossznak minősítők között legjellemzőbb ritkább, mint havonta. Ezt azért érdemes kiemelni, mert a rossz egészségi állapotban lévők jobban rászorulnának a rokonok segítségére. A jó, vagy kielégítő egészségi állapotról beszámolók legalább havonta találkoznak rokonaikkal.

Réteghelyzet szerint a rokonokkal való mindennapos kapcsolattartás az alsó középrétegre jellemző leginkább. A szegények ritkábban, mint havonta találkoznak rokonaikkal, míg a jómódúakra leginkább a heti kapcsolattartás jellemző.

Megkérdeztük, hogy a háztartáson kívül tartják-e a kapcsolatot a megkérdezettek, beszéltek-e valakivel, akár telefonon is a kérdezést megelőző héten. A válaszadók nagy része, $88 \%$-a beszélt valaki olyannal, akivel nem egy háztartásban él. Ezek a beszélgetőpartnerek leggyakrabban családtagok, illetve barátok voltak. Minden tizedik válaszadó viszont nemmel válaszolt erre a kérdésre, tehát a háztartásán kívüli személlyel a kérdezést megelőző egy héten keresztül nem tartott kapcsolatot. Az életkort tekintve a 25-49 évesekre a legjellemzőbb, hogy az adott időszakban csak a közös háztartásban élőkkel beszélt. Az iskolai végzettséget tekintve elmondható, hogy a szakmunkásképzőt végzettek között vannak legtöbben, akik nem tartották a kérdezést megelözö héten a háztartáson kívüliekkel a kapcsolatot. A társadalmi rétegeket vizsgálva a két szélső póluson lévők, azaz a szegények és a jómódúak azok, akikre kevésbé jellemző a háztartáson kívüliekkel való kapcsolattartás. Osztályspecifikus bezáródásról, elszigetelödésről beszélhetünk esetükben (Angelusz R.-Tardos R., 1998).

\section{ERŐS KAPCSOLATOK MÉRÉSE KÜLÖNBÖZŐ SZITUÁCIÓK MENTÉN 2010-BEN - HÁROM SZITUÁCIÓ}

A kérdőívben alkalmunk volt egy úgynevezett névgenerátor módszert is kipróbálni a megkérdezettek társas kapcsolatát vizsgálva. Ennek során három olyan szituációt fogalmaztunk meg, melyek bárkivel megtörténhetnek, így a megkérdezettek könnyen beleélhetik magukat ezekbe a szituációkba. A megkérdezetteket (ego) arra kértük, hogy az egyes szituációk kapcsán jelöljék meg az első három személyt (altert), akitöl, vagy 
akiktől az adott szituációban segítséget, tanácsot, stb. kaphat. A megjelölt személyeket (altereket) ún. névinterpretáló kérdések mentén kellett jellemezniük a megkérdezettek nek, így képet kaptunk arról is, hogy az egyénhez képest milyen csatornákon keresztül áramlanak a különböző típusú erőforrások. Ezek a vizsgálatok az egyének társadalmi integrálódásának fokát, az adott közösség szolidaritását is mutatja.

1. Tegyük fel, hogy Ön beteg lenne, például influenzás, és néhány napra ágyban kellene maradnia, igy nem tudná elvégezni a ház körüli munkákat, a bevásárlást. Kihez fordulna segitségért? Gondoljon az első három emberre, akire ilyen helyzetben számithat.

2. Az emberek néha vendégeket hivnak, vagy vendégségbe, kirándulni, szórakozni mennek. Kikkel szokott Ön igy találkozni? Gondoljon az elsö három emberre, akikkel szivesen tölti így szabadidejét.

3. A családtagokon kivül szokott-e Ön idönként egészen személyes, bizalmas dolgokról, problémákról beszélni másokkal? Ha igen, kikkel? Gondoljon az első három olyan emberre, akikkel ilyen dolgokat meg tud beszélni!

\section{Szituáció}

Betegség esetén jellemzően a nöktöl kérnek segitséget az emberek. A nők mindhárom válaszlehetőségnél (első három ember, akire ilyen esetben számíthat) nagyobb arányban szerepeltek, mint a férfiak. Ez nem is meglepö, hiszen tradicionálisan is a nők feladatai közé tartozik a betegek ápolása, gondozása. Korosztályokat tekintve a betegápolást leginkább (46,2\%) a 60 éven felüliektől várják a megkérdezettek. Öket a középkorúak $(36,5 \%)$, majd a fiatalok $(17,3 \%)$ követik. Betegség esetén a segítség fizikailag közel van, hiszen leggyakrabban attól várják a segítséget a megkérdezettek, akikkel egy háztartásban élnek $(53,6 \%)$. Ha nem is a szomszédságban, de legalább a városban él jellemzően az, akiktől segítséget várnak a nyíregyháziak (24,9\%). A megkérdezettekkel osztályoztattuk a megjelölttel való kapcsolat szorosságát. Az adatok szerint a válaszadók 70\%-a nagyon jó viszonyban van azzal, akitől betegség esetén a segítségnyújtást várja. Majdnem harmadrészük jónak (29,4\%), 15\%-uk viszont maximum közepesnek minősítette az adott kapcsolat szorosságát. Ez arra utal, hogy vannak olyan közeli családtagok, akiktől elvárják ugyan a megkérdezettek a segítséget, de ez inkább valamilyen megszokásra épül, hiszen az emberi kapcsolat nem mondható túl jónak a két fél között. A megkérdezetteknek majdnem tizede $(8,9 \%)$ vár olyan embertől segítséget betegség esetén, akivel a kapcsolatát elégtelennek minősítette. (12. ábra)

A fenti diagramon jól látható, hogy betegség esetén a megkérdezettek elsősorban házastársuktól várják a segitséget, aztán következnek a barátok, majd a szülök. Másod és harmadsorban viszont megnő a barátok szerepe és jelentösége a segitségnyújtásnak ebben a típusában. Láthatjuk, hogy a harmadsorban megjelölt személyek között kimagasló a barátok aránya. Erdemes felhívni a figyelmet a gyermekekre háruló segitségnyújtásra is, amely a másodsorban megjelölt személyek között jelentős. Látható, hogy a 
házastársak hiányát a gyermekektől várt segítség pótolhatja. A szülőktől való segítségnyújtás várása is akkor jelentősebb, ha nincs olyan házastárs, - vagy nem választotta a megkérdezett elsősorban -, akitől ilyen típusú segítséget elvárhat az egyén. A testvérektöl, egyéb rokonoktól elvárt segitségnyújtás ebben az esetben jelentösen elmarad a barátoktól várt eröforrásoktól.

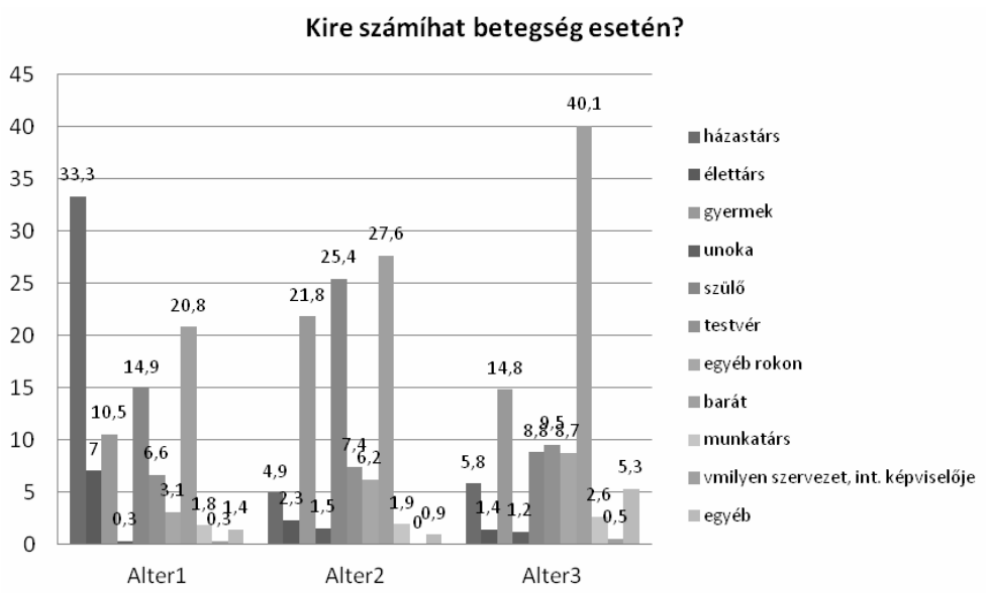

12. ábra - Kire számíthat betegség esetén?

\section{Szituáció}

A következő szituáció a közös szabadidős elfoglaltságot vizsgálta. Talán nem meglepő módon a megkérdezettek vendégségbe, kirándulni, szórakozni leginkább barátaikkal szoktak. A barátok aránya a legmagasabb mindhárom megjelölt személy (alter) esetében. A másod-illetve harmadsorban megjelöltek leginkább az egyéb rokonok közül kerülnek ki. A kapcsolatok szorosságát tekintve érdemes kiemelni azt, hogy a megkérdezettek vendégségbe, szórakozni, kirándulni elsősorban olyan másokkal mennek, akikkel a kapcsolatuk legalább jónak értékelhető. Viszont a másodsorban megjelöltek, a kapcsolatok szorosságát tekintve, már nem állnak olyan közel a megkérdezettekhez: minden negyedik megkérdezett $(21,4 \%)$ olyan személlyel tölti másodsorban szabadidejét, akivel kapcsolatát maximum közepesre értékelte. A szabadidő eltöltése nem korlátozódik a közeli családtagokra, de jellemző az, hogy a megjelöltek, a kérdezettekhez hasonlóan Nyíregyházán élnek. Az első sorban megjelöltek között az egy utcában/egy városrészben lakók, illetve a családtagok szerepelnek nagyobb arányban. A másod és harmadsorban megjelöltek között a városiakon kívül az egy megyében élök aránya növekszik. 


\section{Szituáció}

A családtagokon kívül bizalmas dolgokról a megkérdezettek leginkább barátaikkal beszélgetnek. A barátokon kívül a legjelentősebb a munkatársak aránya az általunk felsoroltak között. A fenti megállapítások a szituációban történő mindhárom említésnél jellemzőek. A kapcsolatok szorosságát tekintve itt is elmondható, hogy míg az első helyen megjelölt személlyel általában jó viszonyt ápol a megkérdezett, a másod-illetve harmadsorban megjelöltekkel már nem ilyen szoros a kapcsolat. Tehát vannak olyanok, akik bizalmas dolgaikat, problémáikat kénytelenek olyan másokkal megosztani, akivel személyes kapcsolatuk nem mondható jónak.

Megvizsgáltuk az egyén és az általa megjelöltek iskolai végzettségét a segitségnyújtás mindhárom szituáció elsö megjelöltjét tekintve. A lenti ábrán látható, hogy míg betegség esetén a homofília jellemző iskolai végzettség tekintetében, addig a szórakozást és a bizalmas információk megosztását figyelembe véve inkább a heterofília jellemző. Azaz az utóbbi két szituációban az egyén saját magánál kvalifikáltabb egyént jelölt meg, akivel első sorban szabadidejét tölti, illetve, akikkel bizalmas dolgairól, problémáiról beszélget. (13. ábra)

\section{A megkérdezett és a megjelölt iskolai végzettsége}

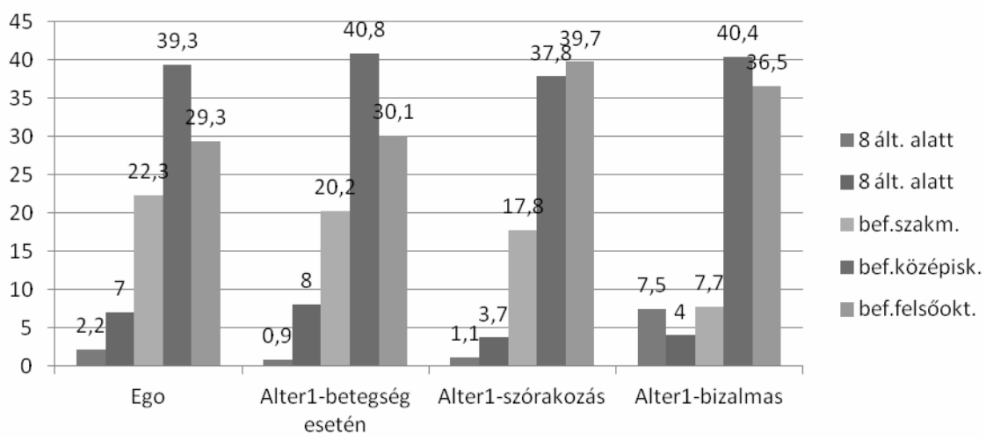

13. ábra - A megkérdezett és a megjelölt iskolai végzettsége.

A megkérdezettek és az általuk megjelöltek, akiktől a különböző szituációban segítséget várnak, korosztályukat tekintve eltérnek egymástól. Itt is inkább a heterofíl kapcsolatok jellemzőek. Míg a válaszadók között a középkorúak vannak legnagyobb arányban, az általuk első helyen megjelölt személyek inkább az idősebb korcsoportból kerültek ki. Ez leginkább a második szituációt tekintve mondható meglepő eredménynek, hiszen ezek szerint a megkérdezettek inkább a tőlük idősebb korosztály preferálják szórakozás, szabadidő eltöltésének tekintetében is. (14. ábra) 


\section{A megkérdezett és a megjelölt kora}

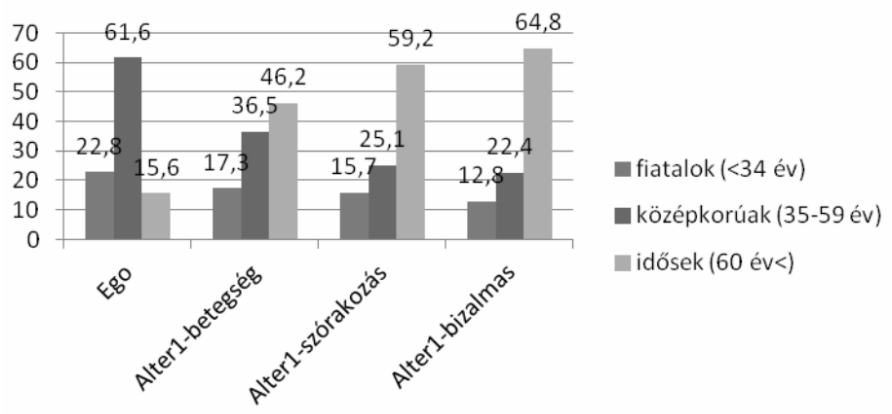

14. ábra - A megkérdezett és a megjelölt kora.

\section{MAGÁNTÁRSASÁGI ÖSSZEJÖVETELEK}

A 2008-as kutatáshoz hasonlóan 2010-ben is vizsgáltuk, hogy a nyíregyháziak milyen gyakran járnak vendégségbe, milyen gyakorisággal fogadnak vendégeket és milyen rendszerességgel járnak el szórakozni. (15. ábra)

\section{Magántársasági összejövetelek (\%)}

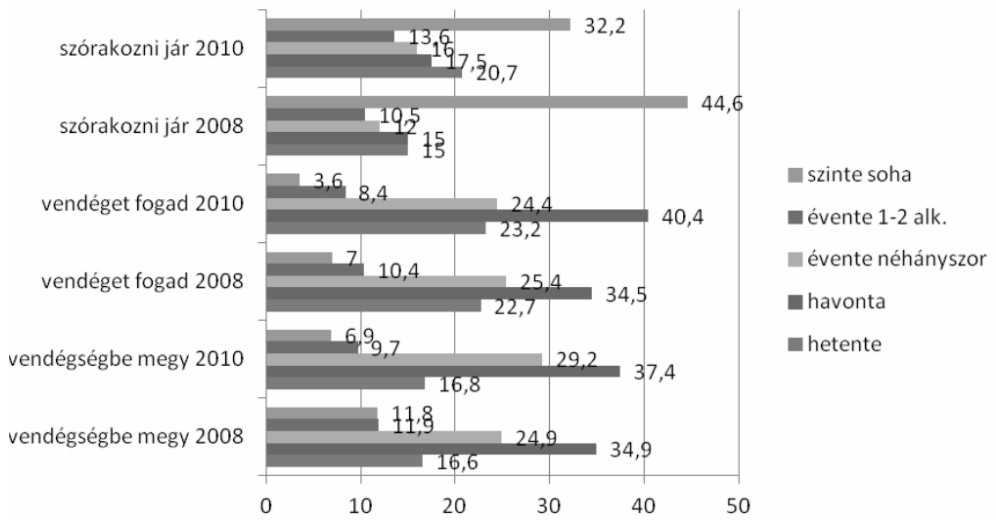

15. ábra - Magántársasági összejövetelek.

A fenti ábra azt mutatja, hogy a megkérdezettek gyakrabban mennek havi rendszerességgel vendégségbe, mint két évvel korábban és csökkent azok aránya, akik nagyon ritkán (évente 1-2 alkalommal) vagy egyáltalán nem mennek vendégségbe. Az adatok szerint a vendégfogadás is gyakoribbá vált a nyiregyháziak körében az elmúlt két évet vizsgálva: 
némiképpen nőtt a hetente vendégeket fogadók, és jelentősen nőtt a havonta vendégeket fogadók aránya a megkérdezettek között. Korábbi országos vizsgálatok kimutatták, hogy az emberek fontos társasági és szórakozási eseménynek tartják a családdal együtt töltött hétvégéket, közös születés-és névnapokat. Ezek egyfajta ellenpontot jelentenek az egyéb társaságok, klubok, szervezetek hiányával szemben. (Utasi, 2011) Tehát elképzelhető, hogy a nyíregyháziak is azért jártak össze gyakrabban 2010-ben, mint két évvel korábban, mert társas igényüket inkább ezekben a családi közegekben igyekeztek kielégíteni. Ezt támasztja alá az a fentebbi megállapítás, hogy a nyíregyháziak háromnegyede nem tartozik semmilyen klubhoz, szervezethez sem, amelyek például a magántársasági együttlétek számát is gyarapíthatná. Nagy változás 2008-hoz képest, hogy a városlakók 32,2\%a nem jár el szórakozni, szemben a 2008-ra jellemzö 44,6\%-kal. Ezzel együtt nött a hetente, havonta szórakozni járók aránya. Ugyancsak korábbi országos kutatásokból derült ki, hogy minél nagyobb valakinek a baráti társasága, annál gyakrabban él intenzív társasági életet. (Utasi, 2011) Mint azt fentebb láttuk is, a vizsgált két év során a nyíregyháziak körében a barátságok növekedését jelezhettük, így ez együttjárást mutathat a magántársasági összejövetelek gyakoribbá válásával. Adataink szerint szignifikáns kapcsolat van aközött, hogy ki hány baráttal rendelkezik és milyen gyakran él társasági életet.

\section{ÖSSZEFOGLALÁS}

A barátságok alakulását tekintve pozitív irányú változás következett be a városban, hiszen növekedett azok aránya, akik 5-9 barátot tudhatnak maguk mellett. Közöttük negyobb arányban vannak a nők, amit ugyancsak pozitív jelenségként könyvelhetünk el, hiszen a nők erőteljesebb és stabilabb társas kapcsolatrendszere képes olyan muníciókkal ellátni a nőket, melyek segítenek számukra a további erőforrások áramoltatásában. Az, hogy a nök átlagosan több barátról számoltak be, lokális jelenségnek számít, melyet érdemes részletesebben is megvizsgálni a következőkben. Pozitív elmozdulásnak számít az is, hogy 2010-ben az alacsonyabb iskolai végzettségüek átlagosan több barátról számoltak be, mint két évvel korábban. A gazdasági aktivitást tekintve egyik oldalon a teljes munkaidőben dolgozók, a másikon pedig a tartós munkanélküliek azok, akik a „barátvesztö" kategóriába sorolhatók.

A barátok számának alakulását adataink szerint alapvetően három tényező határozza meg: az egyén iskolai végzettsége, szubjektív egészségi állapota, valamint családi állapota, tehát olyan szocio-demográfiai háttérváltozók, melyek magának az életminőségnek is meghatározó tényezői.

A természetes támogató rendszert vizsgálva pozitív irányú elmozdulásról adhatunk számot, hiszen a vizsgált két év során csökkent azok aránya, akik bizonyos, a természetes támogató rendszert mozgósító kérdésekben nem számíthatnak sem közeli, sem távoli családtagjaikra, rokonaikra, sem pedig barátaikra. Növekedett azok aránya, akiknek van olyan rokona, családtagja, barátja, ismeröse, akinek a segítségére tud számíta ni iskoláztatással, továbbtanulással kapcsolatban, illetve, aki jó orvost tud ajánlani adott esetben. Fontos kiemelni, hogy a jó állás, munkahely megszerzéséhez a barátok segítségnyújtásának nagyobb szerepe lehet a nyíregyháziak esetében, mint országosan. 
A közösségi élet egyes területeit, különbözö klubokhoz, vallási közösségekhez, pártokhoz való tartozást vizsgálva megállapíthatjuk, hogy a nyíregyháziak jelentős része még mindig kívül marad ezeken a közösségi tereken. Nagyon kicsi, pozitív elmozdulás látszik, amelyből jelentős lehet, hogy a fiatalok és az alacsonyabb iskolai végzettségüek azok, akik inkább beléptek ezekbe a terekbe az elmúlt két év során.

A rokonokkal, barátokkal, szomszédokkal való kapcsolattartás gyakoriságát tekintve megállapíthatjuk, hogy a vizsgált két év során csökkent a rokonokkal való kapcsolattartás gyakorisága, viszont növekedett a szomszédokkal való napi kapcsolat. A barátokkal való kapcsolattartás is inkább a heti rendszeresség felé mozdult el.

A Nyíregyházán élők társas kapcsolati rendszerének több dimenzióját tudjuk megvizsgálni a helyi panelkutatás adatai alapján. Ennek során elsősorban a helyiek erős kapcsolatairól kapunk képet, hiszen látjuk, hogyan változik az évek során a barátok átlagos száma, hogyan alakul természetes támogató rendszerük, kikkel és milyen gyakran tartják a kapcsolatot a helyiek. Azt is részletesen vizsgálhatjuk, hogy milyen közösségekhez csatlakoznak évről évre a nyíregyháziak, és milyen jellemzőkkel bír a helyiek magántársasági összejövetele, vendégségbe mennek vagy vendégeket hívnak-e gyakrabban, esetleg szórakozási szokásaik változnak. E jelenségek lokális és panelszerủ vizsgálata jelenleg egyedülálló hazánkban.

\section{IRODALOM}

1. Albert F.-Dávid B. (2007): Embert barátjáról. A barátság szociológiája. Századvég, Bp.

2. Angelusz Róbert-Tardos Róbert: A kapcsolathálózati erőforrások átrendeződésének tendenciái a kilencvenes években. Társadalmi Riport 1998. Tárki, BpAngelusz Róbert-Tardos Róbert (2006): Hálózatok a magyar társadalomban. In: Kovách Imre (szerk.) Társadalmi metszetek. Érdekek és hatalmi viszonyok, individualizáció és egyenlőtlenség a mai Magyarországon. Napvilág Kiadó, Bp.

3. Dávid B.-Albert F. (2005): „Kit nevez Ön barátnak?” A barátság szociológiai megközelítésben. In: Századvég, 2005/4

4. Kopasz M.-Szántó Z.-Várhalmi Z.: A magyar háztartások tagjainak kapcsolatháló-dinamikája 1997 és 2007 között. tarki.hu/hu/news/2008/kitekint/20081014_szanto.pdf

5. Szabó L.: A társadalmi támaszt nyújtó személyes kapcsolatháló és a szubjektív életminőség összefüggései az egészséges és a mozgáskorlátozott személyek körében. PhD értekezés. Budapest, 2003.

6. Utasi Á.: A bizalom hálója. Új Mandátum, Bp. 2002.

7. Utasi Á.: Baráti közösségek és magántársaságok - A közélet iskolái. In: Utasi Á. (szerk.): Közösségi kapcsolatok és közélet. MTA PTI, Szegedi tudományegyetem BTK Szociológia Tanszék, Belvedere Meridionale, Budapest-Szeged, 2011

8. Újratervezés. Életutak és alkalmazkodás a rendszerváltás évtizedeiben. Kutatási jelentés a „Háztartások életút vizsgálata” (HÉV) alapján (2008). Szerk.: Kolosi T.-Tóth I.Gy. Tárki, Bp. 